\title{
Cultivation of Critical Thinking Skills in the Course of Readings from British and American Press
}

\author{
Weilian Ma, Jie Han \\ College of Foreign Language Education and International Business, Baoding University, Baoding, China \\ Email: linda0180@126.com
}

How to cite this paper: Ma, W. L., \& Han, J. (2020). Cultivation of Critical Thinking Skills in the Course of Readings from British and American Press. Creative Education, 11, 1351-1356.

https://doi.org/10.4236/ce.2020.118099

Received: July 23, 2020

Accepted: August 16, 2020

Published: August 19, 2020

Copyright (อ 2020 by author(s) and Scientific Research Publishing Inc. This work is licensed under the Creative Commons Attribution International License (CC BY 4.0).

http://creativecommons.org/licenses/by/4.0/

\begin{abstract}
The cultivation of critical thinking ability has become the central issue of higher education reform. It is an indispensable part of college education that college students are expected to pursue and achieve in their college years. The course of Readings from British and American Press can serve as a vital approach to help learners to construct meaning and cultivate their critical thinking ability. This paper tries to explore the teaching strategies from three stages-pre-class, in-class and post-class to develop students' critical thinking ability.
\end{abstract}

\section{Keywords}

Critical Thinking, Teaching Strategies, Readings from British and American Press

\section{Introduction}

Critical thinking has been widely debated by the education community since the 1960s, especially in the 21st century. It has become a popular word in education, and has become a must-have quality of thinking for everyone (Chen, 2015). What's more, students today need the ability to think independently, to solve problems, and to meet the changes and difficulties in their lives. The lack of critical thinking skills might affect not only students' learning success but also their personal lives when they graduate, and enter the workforce. Currently, critical thinking has been attracting many researchers' and teachers' attention. Philosophy of The United States in The Delphi Report in 1990 shows an authoritative and comprehensive definition: Critical thinking is a purposeful, self-regulatory judgment process, as a result of interpretation, analysis, evaluation, reasoning, 
and explanation of the evidence, concepts, methods, standards that the judgment is based on. Paul \& Elder believe that critical thinking refers to the ability of an individual to consciously think with appropriate evaluation criteria in order to determine the real value of something and finally make reasonable judgments (Yin, 2004). Even though there is no unified definition of critical thinking, it has been attracting many teachers' and researchers' attention. As an essential part of China's higher education, the reform of College English teaching in our country must focus on the cultivation of critical thinking ability, serve the purpose of improving the teaching quality of colleges and universities, and serve the overall situation of cultivating high-quality and innovative talents for China (Wen, 2018).

Readings from British and American Press is one of the traditional courses for senior English majors, and non-English majors also choose it as an elective course in many colleges and universities. How to develop the ability of critical thinking in the course of Readings from British and American Press is the task that the author tries to explore.

\section{Cultivation of Critical Thinking Skills in the Stage of Pre-Class}

Cultivation of critical thinking skills in the stage of pre-class is embodied in the careful choice of reading materials. Reading materials play a quite important role in the course of Readings from British and American Press. The most striking feature of this course is its strong timeliness. Once a book is published, it is doomed to be outdated and delayed. In order to get involved in the most trending, fresh, novel news, we would like to choose the current affairs from British and American Press. Since we don't have a fixed textbook, the choice of these materials should be considered carefully and cautiously. It cannot be denied that these readings themselves could possess the quality of critical thinking.

The inherent attribute of Readings from British and American Press makes it possible to have more unparalleled advantages in cultivating students' critical thinking skills. All the readings come from real life and cover all kinds of fields. The papers require students to identify, analyze, interpret and evaluate the topics by their cognitive competence. When it comes to the choice of teaching materials, teachers are supposed to attach great importance to the trending, interesting and controversial topics. These topics can trigger or spark the passion of students to examine, analyze and solve problems and provide them with free space for thinking. It can be said that critical reading is an important way or even medium for the development and implementation of critical thinking $(\mathrm{Hu}$, 2015).

For example, in the past semester, the whole world experienced a special and unusual period because of the pandemic COVID-19. The author chose some debatable, novel and related topics such as Virus Threatens Chinese Traditions of Chopsticks and Family-Style Meals, Can We Put a Price Tag on a Life? The topics are interesting, meaningful and closely related to the students' lives, and 
more importantly, they can raise more thinking to the students. Take the news Virus Threatens Chinese Traditions of Chopsticks and Family-Style Meals as an example: Sharing food with family and friends is a central feature of how Chinese people convey affection, and it is deeply rooted in China. Many people concerned the country's long tradition could also accelerate the spread of the coronavirus. Under such circumstances, the government called on people to use serving chopsticks when they dine out. When students read such news, they may have questions in their minds: "Can serving chopsticks undermine the expression of closeness? Would you like to use serving chopsticks when you have a dinner with your friends?" These topics are suitable for reading materials. On the one hand, students feel close and familiar with these subjects; on the other hand, they are likely to think further and deeper. Their interest can be largely stimulated.

\section{Cultivation of Critical Thinking Skills in the Stage of In-Class}

Cultivation of critical thinking skills in class is mainly reflected in the teaching mode the teacher adopted. Communicative Language Teaching is the most suitable for the face-to-face teaching in class. It is an approach to language teaching that emphasizes interaction as both the means and the ultimate goal of study. Language learners learn and practice the target language through the interaction with one another and the instructor by using authentic texts (Yuan, 2018). The aim of this study was to develop a deep understanding of authentic interaction in English as a foreign language classroom so as to improve communicative language teaching approach. It emphasizes the interaction between teachers and students, students and students. It also advocates a student-centered classroom and underlines the importance of autonomic learning and collaborative learning. The cultivation of critical thinking and the teaching concepts complement each other.

How does the author combine communicative language teaching and cultivation of critical thinking? Here comes the practice: There are about 30 students in each class, and in order to facilitate teaching management and students' interaction, the author divides the whole class into five different study groups. Each study group has six members or so, and each has different tasks to fulfill according to the topic they choose. We may take the topic Hot Issues in Today's World as an example. We chose the conflicts between Israel and Palestine in the Middle East. The first group may collect information about the history of Palestine; the second group may gather information about the history of Israel; the third group may provide us with some information about Jerusalem, Gaza strip, West Bank, Hamas, Fatah, etc.; the fourth group may inquire into the reasons behind the conflicts between Israel and Palestine; the fifth group may search some other conflicts in other countries such as Iraq, Afghanistan, etc. During the process of fulfilling the tasks, students have more chances to gather, think, analyze, discuss, summarize information and finally report their results. In this sec- 
tion, the teacher also guides students to conduct self-reflection, monitor their own thinking process, self-regulate their thinking ability, and make further rational reasoning and evaluation, so as to develop their critical thinking ability.

Teaching mode varies according to the topic we deal with. The news Heels at High Water centers about Japanese women rebelling against painful dress codes. Dress codes at many Japanese firms are rigid, and employers require women to wear high heels at work. For this topic, the author organized a group debate in the class. The debate topic is: "Is it gender discrimination to require women to wear high heels at work?" The debate was enthusiastic and successful, which proved the students' careful preparation and deep thinking. For this topic, the cultivation of critical thinking ability is mainly through guiding students to think and discuss, put forward their views and elaborate, analyze positive and negative points of view, and guide students to think about the reasons behind it.

The news Can We Put a Price Tag on a Life? raises an issue that economists have long grappled with: How can a society assess the trade-off between economic well-being and health? A legal scholar, heading the White House office in charge of valuations, once wrote, "A program that saves younger people is better, in this sense, than an otherwise identical program that saves older people." That means they put a price tag on a life, and the worth of older people was devalued. They thought older people's lives were not worth saving compared to younger ones. However, the Chinese government had been trying its best to save all the lives regardless of their race, gender, and age. Such news provides us with an objective angle to penetrate American social values. For this topic, the author arranged group discussion about different social values between China and America among group members. The students are required to work cooperatively in groups to outline the overall framework of the reading. During the discussion, the news is carefully analyzed and evaluated and students could combine their language skills with their viewpoints, which is closely related to the improvement of critical competence.

\section{Cultivation of Critical Thinking Skills in the Stage of Post-Class}

Post-class assignment is also a perfect opportunity to develop students' critical thinking ability. Teaching time is limited, but reflection to questions is limitless. Under the era of Internet+, students have more access to vast, authentic, rich and colorful resources. College students are fast learners to the mobile network technology, and educators also have to study the characteristics of Internet+ to meet the new challenge.

In the class, educators could make good use of the texts, pictures, animation, videos, etc to spark students' enthusiasm to study and students could present their reports based on multi-media courseware. After class, students can easily get abundant reading materials from the Internet, and the resources could extend students' reading and thinking outside the classroom. Students could upload their assignments, reports, and writings through autonomous learning plat- 
form, which offers a perfect opportunity for students to gain, organize, and summarize their information. All in all, the teaching methods should be updated to achieve the teaching objectives more effectively.

The author chooses a different topic for each week and requires the students to write a short essay related to the topic after class. The students have enough time to search, read, discuss, reflect and finally write out the essay. The process of writing is the process of critical thinking. The essay is also a summary to the teaching topic after deep learning and profound thinking. The mode of "reading-discussion-writing" could help students get information and thinking ability. The essay is also a perfect presentation of their ideas and opinions. The writing of the essay could definitely develop and enhance the ability of critical thinking and solving problems. For example: When the epidemic first broke out, a wave of hate crimes against Asians has cascaded throughout Western countries. A Fox News host even demanded China officially apologize to the world for causing the epidemic. In response to this issue, the author assigned an essay to the students, requiring them to write their thinking about the groundless accusations on the autonomous learning platform. The author was delighted to see that most students could think about the issue from a critical, rational and reasonable perspective. In the end, the author uploaded a video made by the hostess Liu Xin from GGTN and highlighted her comments on this issue: "A disease can break out in any part of the world because of all kinds of reasons. Does the world ask these cities, villages, or countries to apologize? No, because viruses don't care about borders. No, because it's counterproductive." The hostess Liu Xin's comments could help students think deeper and further as well as broaden their horizon and give them information. When the students learn to treat various opinions appropriately they can make sound judgment independently. In this process, they set up correct mainstream values, cultivate a global vision, and develop a sense of citizenship.

\section{Conclusion}

This paper carries out the teaching practice of integrating Readings from British and American Press with the cultivation of critical thinking ability through effective teaching design. The essence of news reading is the interaction between the reader and the reading materials. The cultivation of critical thinking ability in news reading not only improves learners' cognitive skills in interpretation, analysis, evaluation and reasoning, but also cultivates their affective dispositions in critical thinking. Therefore, Readings from British and American Press should not only teach students to "read and know", but also guide them to "read and question" even "read and create". In view of this, this study attempts to explore the methods and ways of cultivating the critical thinking ability of college students, and to provide practical references for the teaching of the course Readings from British and American Press.

Based on the content and design of teaching Readings from British and American Press, students' critical thinking abilities are exercised in applying 
what they have learned to solve problems. Through teachers' questioning or guiding, students can ask questions by themselves. Students are inspired to think, to discuss, and encouraged to cooperate with others and explore independently, which not only enables them to have a higher-level understanding of discourse, but also improves their critical thinking ability.

\section{Conflicts of Interest}

The authors declare no conflicts of interest regarding the publication of this paper.

\section{References}

Chen, Z. H. (2015). Critical Reading and Critical Thinking. Foreign Language Education in China, 2, 4-11.

$\mathrm{Hu}, \mathrm{W}$. (2015). Practice and Research of Seminar Teaching Method in Japanese Intensive Reading Course. Japanese Learning and Research, 2, 90-98.

Wen, Q. F. (2018). Cultivating Key Competencies through University Foreign Language Courses in the New Era: Reflections and Suggestions. Foreign Language Education in China, 1, 3-11.

Yin, X. F. (2004). A Study on Innovative Textual Reading: A Teaching Pattern and Its Significance. Foreign Languages in China, 1, 41-45.

Yuan, C. Y. (2018). Exploring Features of Critical Thinking Teaching in College English Reading Classes. Journal of Guangdong University of Foreign Studies, 4, 109-117. 